\title{
Contribution of Visionary Leadership, Lecturer Performance, and Academic Culture to the Competitiveness of Islamic Higher Education in Indonesia
}

\author{
Prim Masrokan Mutohar ${ }^{1 *}$, Jani $^{2}$, Hikmah Eva Trisnantari ${ }^{3}$ \\ ${ }^{1}$ Graduate School of IAIN Tulungagung, East Java Indonesia \\ ${ }^{2}$ Faculty of Tarbiyah and Education of IAIN Tulungagung, East Java Indonesia \\ ${ }^{3}$ Graduate School of STKIP PGRI Tulungagung, Esat Java Indonesia
}

DOI: $10.36348 /$ jaep.2020.v04i02.002

| Received: 06.01.2020 | Accepted: 21.01.2020 | Published: 16.02.2020

*Corresponding author: Prim Masrokan Mutohar

\section{Abstract}

This research aims to describe visionary leadership, lecturer performance, and academic culture in improving the competitiveness of Islamic tertiary institutions in Indonesia. Quality and highly competitive education is a problem faced by the majority of educational institutions in Indonesia. Leadership is thought to be able to create performance and academic culture in achieving the vision and mission of the institution and be able to meet the expectations of the community and education stakeholders. In order to achieve these objectives properly, a quantitative research approach with survey design was used. The questionnaire that has been tested for validity and reliability is used as a tool in exploring the data needed in research. This research was conducted in several Islamic Higher Educations in Indonesia, with a population of 35,705 students. The questionnaire was filled by 1135 students who were sampled in this study with random sampling techniques. The collected data were analyzed using descriptive statistics and path analysis. The results showed that visionary leadership, lecturer performance, academic culture, had a significant contribution to the competitiveness of Islamic Higher Education in East Java. This finding has the implication that the better visionary leadership in higher education, the better the performance of lecturers and academic culture and institutional competitiveness. The better the performance of lecturers, the better the academic culture and competitiveness of the institution. This finding shows that visionary leadership is the key to success in improving the quality and competitiveness of educational institutions in the global era.

Keyword: Visionary Leadership, Lecture Performance, Academic Culture, Competitiveness of Islamic Higher Education.

\footnotetext{
Copyright @ 2020: This is an open-access article distributed under the terms of the Creative Commons Attribution license which permits unrestricted use, distribution, and reproduction in any medium for non-commercial use (NonCommercial, or CC-BY-NC) provided the original author and sources are credited.
}

\section{INTRODUCTION}

Islamic higher education in Indonesia faces various challenges in managing institutions to be of high quality and competitiveness. The national policy about the higher education system, which is oriented towards improving quality on a continuous basis, is a grave concern by every institution of higher education. Quality higher education institutions will be more in demand by the community and education stakeholders $[1,2]$. Public interest and support for educational institutions must be the primary concern to be realized by the management of existing educational institutions. Institutional decisions made by leaders in improving the quality of internal and external services have a significant contribution to the process of improving the quality and competitiveness of higher education.
Islamic higher education in Indonesia has enormous and complex challenges, namely: (1) the challenge of increasing added value in increasing national productivity, (2) the challenge of conducting a thorough assessment in the process of cultural transformation that occurs in the life of traditional communities into modern society and its implications in developing quality Human Resources, (3) the increasingly fierce competition in increasing the competitiveness of the Indonesian people in the global era. These challenges must be positively responded to by universities in general, including Islamic religious colleges [3].

Improving the quality and competitiveness of higher education is closely related to the development of science and technology in a rapidly developing 
world. This development requires universities to be able to respond well to be able to meet the demands and needs of educational stakeholders. This development brought changes in almost all aspects of human life that demand mastery of science and technology in solving various problems that exist in the life of society, nation, and country $[4,5]$. This change also brought people into an era of increasingly fierce global competition between nations and countries. In order for the Indonesian people to be able to play a role in the global competition between nations, they must develop and improve the quality of their human resources. Improving the quality of human resources can be carried out by efforts to improve the quality of education carried out in a planned, directed, intensive, effective, and efficient manner in the whole education process.

Quality improvement and competitiveness that occur in higher education cannot be separated from visionary leader who is able to see opportunities and challenges in the future, service excellence in improving internal quality and services for educational services, lecturers' performance as the spearhead in improving the quality of education and learning, as well as academic culture which is the key in realizing quality and competitive education [6,7]. Leaders are demanded to have high managerial skills in order to create performance-oriented to the creation of quality and work productivity of all personnel in educational institutions so as to be able to carry out continuous improvement in accordance with the demands and needs of the community and the development of science and technology [8, 1]. Improving the quality and competitiveness of higher education requires leadership that is oriented to quality and able to see opportunities and be able to fix weaknesses to seize opportunities in a sustainable manner in the higher education system.

Improving the quality and competitiveness of higher education requires quality-oriented and robust leadership. The Chancellor, as the leader of higher education, plays a crucial role in the success of quality improvement programs in tertiary institutions. The Chancellor must have the ability, expertise, and skills in a quality initiative and be able to empower potential human and non-human resources to improve the quality and competitiveness of higher education. This condition is critical to know in-depth so as to obtain a comprehensive picture of the real conditions of visionary leadership, excellent service, lecturer performance, academic culture, and the quality and competitiveness of Islamic tertiary institutions in Indonesia. This condition can be used as material for making policies in making improvements to Islamic Religious Colleges in a sustainable manner so that they become tertiary institutions that have high competitiveness in the current global era.
Based on the explanation above, there are several reasons that form the basis for conducting this research. First, leadership is the key to success in the organizational system in educational institutions. Visionary, creative, and innovative leaders will be able to deliver quality and highly competitive educational institutions. Secondly, the performance of lecturers in tertiary institutions has a considerable role in creating quality tertiary institutions. Third, the academic culture in universities must be adequately realized in order to be able to develop dynamically, productively and competitively in facing competition in the global era. Fourth, the quality and competitiveness of tertiary institutions will not be adequately realized if the leadership, performance, and culture that exist in tertiary institutions cannot be improved for the better. This study will examine empirically that the leadership, lecturer performance, and academic culture variables are essential to consider in improving the quality and competitiveness of higher education. Therefore, there are several research issues that will be examined, namely: (1) Is there a significant contribution between visionary leadership and the performance of Islamic Higher Education lecturers in Indonesia, (2) Is there a significant contribution between visionary leadership and lecturer performance with the academic culture of Islamic Higher Education in Indonesia, (3 ) Is there a significant contribution between visionary leadership, lecturer performance, and academic culture with the competitiveness of Islamic Higher Education in Indonesia significant contribution between visionary leadership and Islamic Higher Education lecturer performance in Indonesia, (2) Is there a significant contribution between visionary leadership and lecturer performance with the academic culture of Islamic Higher Education in Indonesia, (3) Is there a significant contribution between visionary leadership, lecturer performance, and academic culture with the competitiveness of Islamic Higher Education in Indonesia.

\section{LITERATURE REVIEW \\ Visionary Leadership}

Visionary leadership is the ability possessed by leaders of educational institutions in knowing their strengths and predicting opportunities, challenges that must be faced, threats that arise in advancing educational institutions, and the ability to influence others to be invited to work together in organizational systems to achieve goals effectively and efficiently [9]. Visionary leadership in organizing educational institutions can be seen from the ability to make proper planning in realizing success in carrying out its leadership responsibilities which is realized by the formulation of a vision that is able to create creativity and togetherness in professional development and is focused on improving the quality of performance in improving the quality of education that is more quality. Effective visionary leaders have a strong ability to communicate visions that attract and inspire followers 
[10-13]. Visionary educational leadership can, in turn, demonstrate quality leadership with the following characteristics: (1) there is high personal integrity, (2) enthusiasm for the development and improvement of the quality of the institution they lead, (3) able to develop organizational climate and culture, (4) having power in organizational management, (5) being assertive and fair in taking actions and institutional policies [14].

\section{Lecturer Performance}

The term lecturer performance is essentially a concept that is quite broad in meaning because it is closely related to the behavior of individual lecturers in carrying out work that is their duty and responsibility in higher education. Landy and Farr [15] provide an explanation that: "The point is that performance is the behavior of the widest variety." This shows that: to obtain excellent and quality performance, it is necessary to have a process and sustainable management in order to get results that are desirable in carrying out work as explained by Baird [16] that: "Performance management is a continuous process of working with people to accomplish desired results". Cascio [17] provides an explanation that: "Performance refers to employee's accomplishment of assigned tasks." This concept shows that performance is seen as an embodiment of the achievement or fulfillment of tasks that are charged to it.

Performance is closely related to behavior, results, and effectiveness that exist in the organizational system. Personnel behavior related to all activities carried out in achieving organizational goals. The effectiveness relates to the steps taken in the implementation of work and work results. The organizational system focuses on aspects of the work process within the institution. Performance is the peak condition of interrelated behavior between skills, efforts taken, and external conditions [18, 19]. Performance is a performance in carrying out its duties and responsibilities in accordance with the attitudes, knowledge, skills, and motivation that it has in carrying out work [20-22]. Existing performance in educational institutions will determine work productivity that will bring progress or setback for the organization. Therefore, there is a need to improve performance in the educational system's organizational system continuously.

\section{Academic Culture}

Higher education as an educational institution has an academic culture that needs to be developed in achieving the vision and mission of the institution. This academic culture can be used as a hallmark of higher education in improving the quality and competitiveness of institutions. Quality institutions have a functional and robust academic culture in realizing organizational goals, so an influential academic culture is essential to be realized in improving the quality and effectiveness of education [23-26]. Academic culture is closely related to the system of shared meaning by all members of educational institution organizations in the form of educational values, academic norms, beliefs, traditions, and ways of thinking shared by all academic communities which can distinguish one institution from another. Academic culture places more emphasis on the socialization process of organizational members to develop perceptions, values, and beliefs in education. Robbins [27] explains that organizational culture is a shared perception shared by every member of the organization that describes the behavior that is carried out in an existing organizational system. Organizational culture and academic culture in higher education can be said to be an invisible organizational strength but can be perceived and perceived together by members of the organization $[23,25,26]$. The results of perceptions held by every individual in the education institution can influence behavior positively for all members of the organization in carrying out its duties and responsibilities. This academic culture has the function of (1) giving a sense of identity to the academic community, (2) raising commitment to the institution's mission, (3) guiding and shaping behavioral standards, and (4) increasing social system stability [28, 29].

\section{Higher Education Competitiveness}

Quality higher education is education that is able to produce graduates who have academic and vocational competencies both personally and socially so that they have life skills. Quality universities are universities that are able to equip all students to have life skills that are in accordance with established quality standards. Improving the quality of higher education can be carried out by (1) efforts to improve the quality of education academically to provide necessary skills needed by students in accordance with the needs and demands of the times, (2) improving the quality of education-oriented to life skills that must be possessed by students [30]. Higher education has the responsibility to prepare quality human resources in order to be able to improve the competitiveness of education in the current global era.

Competitiveness is the concept of comparing the ability and performance of educational institutions so that it is in demand by customers. Higher education competitiveness is closely related to the ability of higher education institutions to show better performance and output that is ready to use and are in demand by education stakeholders. The ability that must be possessed by tertiary institutions is closely related to (1) the ability of tertiary institutions to strengthen their market share, (2) the ability of tertiary institutions to connect with their environment, (3) the ability of tertiary institutions to improve performance in a sustainable manner, (4) the ability of tertiary institutions high in upholding favorable positions [31]. The competitiveness found in tertiary institutions is essential to run an organization internally and externally 
or in other words able to proactively respond to the target market of its business [32, 33]. Further explained that the dimensions of the competitiveness of higher education organizations are closely related to quality, cost, delivery, and flexibility.

\section{Conceptual Framework}

Visionary leadership applied in educational institutions is able to improve excellent service in building empathy through moral actions and services as well as the ability to obtain opportunities in setting student goals, decision making, and problem-solving [34]. Leadership behavior significantly influences the performance of academic services [35]. This finding shows that the better the leadership that is applied in higher education, the better the academic services available in tertiary institutions. Leadership has a very positive impact on increasing job satisfaction and employee performance [36]. Leadership is sure to influence the culture of a group or organization [37]. The essential function of leadership is to manipulate culture [38]. Organizational culture is a consequence of visionary leadership [39, 40, 41]. Creemers and Reynolds [28] research results show that leadership has a role in creating organizational reality and shape organizational culture. Leadership will influence the spirit of group work [42]. This finding is reinforced by Hoy and Miskel [22], who explains that the taskoriented and human-oriented leadership style will affect the morale of the staff. In this case, Mantja [28] also explained that one factor that played an essential role in creating high morale was leadership behavior.

The quality and competitiveness of higher education are influenced by several variables, including visionary leadership, service excellence, lecturer performance, and academic culture. This has been proven from the results of several studies conducted by experts in the previous decade. Likert's research results suggest that leadership is a significant factor in determining organizational success [43]. On the other hand, the results of Reimer's research cited by find that group productivity is higher under task-oriented leadership styles than leadership styles that are oriented towards human relations [44]. However, it can be concluded that the leadership style has a strong relationship directly with performance, which will have implications for productivity. Leadership behavior is at the core of various conditions within the organization [45]. This means that the good and bad conditions in educational institutions are more determined by leadership behavior, including the formation of excellent service, lecturer performance, and academic culture in higher education. The quality and competitiveness of higher education be realized by improving the variables mentioned above. Based on this description, the conceptual framework of the study can be explained as follows:

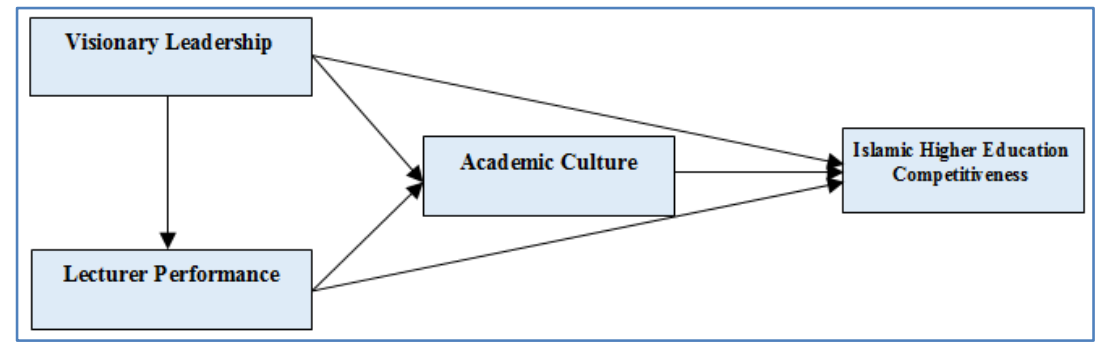

Fig-1: Research Conceptual Framework on Visionary Leadership, Lecturer Performance, and Academic Culture on Islamic Higher Education Competitiveness [34, 37, 36].

Based on the conceptual framework and the problem formulation in this research, the following research hypotheses can be formulated: (1) there is a significant contribution between visionary leadership and lecturer performance, (2) there is a significant contribution between visionary leadership and lecturer performance with academic culture, (3) there is a significant contribution between visionary leadership, lecturer performance, and academic culture with competitiveness of Islamic higher education in Indonesia. The competitiveness of Islamic higher education in Indonesia will be realized if there is visionary leadership, productive lecturer performance, and influential academic culture. This is because the leader has the strength and ability to drive the existing organizational system in higher education so that all human resources, including lecturers, will be able to improve work performance and high productivity. The leader will also be able to shape the organizational culture and academic culture in the college. This is because organizational culture is one of the variables that determine the success of a job [46, 28].

\section{MATERIALS AND METHODS Research Design}

This study aims to describe and explain the contribution of visionary leadership, lecturer performance, and academic culture to Islamic Higher Education competitiveness in Indonesia. In order to achieve these objectives well, this research is considered appropriate using a survey research design with a "cross-sectional survey" approach. This research is also descriptive because it seeks to display the phenomena observed today [47]. Called correlational because this study seeks to explain whether there is a contribution between research variables based on the size of the correlation coefficient [48-50, 47]. This study uses a path analysis design. The path analysis 
research design can estimate the magnitude of the causal contribution of a number of variables and the hierarchy of the position of each variable in a series of causal contributions, both directly and indirectly [51]. The path analysis model can be used to analyze the strength of the contribution of exogenous variables to endogenous variables by using regression stages. Endogenous variables are variables that are influenced by other variables, while exogenous variables are variables that are not influenced by other variables in one research model [52].

\section{Population and Sampling}

The population is the whole object to be observed and meets the requirements or phenomena that have been determined in advance [53]. Dalen [54] argues that a population is a group of humans or something that really exists and is well formulated. The explanation shows that the population is a collection of individuals with predetermined qualities and characteristics. The intended population in this study is the whole object that can be observed and meets the requirements and has specific characteristics that have been determined and well-formulated by researchers. The population in this study was all students of Islamic Higher Education in East Java, Indonesia amounting to 35,705 . The sample is part, or representative of the population studied [50]. The sample size in this study was determined based on the sampling table with a significance level of $95 \%$ alpha 0.01 [55]. Based on the table, the number of research samples can be determined by 1135 students. The sample size of each tertiary institution can be explained in the form of a table as follows:

Table-1: Population and Research Samples

\begin{tabular}{|c|c|r|c|r|}
\hline No & Higher Education & Population & Sample Calculation & Sample \\
\hline 1 & Islamic Higher Education 1 & 17.865 & $17.865: 35.705 \times 1135=567,9$ & 568 \\
\hline 2 & Islamic Higher Education 2 & 9.112 & $9.112: 35.705 \times 1135=289,6$ & 290 \\
\hline 3 & Islamic Higher Education 3 & 8.728 & $8.728: 35.705 \times 1135=277,4$ & 277 \\
\hline & Total of Samples & 35.705 & & 1.135 \\
\hline
\end{tabular}

Source: Documentation from each Islamic College in East Java, Indonesia

A sampling at each Islamic tertiary institution was carried out using random sampling [53]. Random sampling is random sampling and provides equal opportunity for the entire population to become a research sample [48]. This method is used with the consideration that all students have the same opportunity to be sampled in this study.

\section{Instrumentation}

The instrument used to collect data in this study was a questionnaire that had tested its validity and reliability. This questionnaire was used to express students' perceptions of visionary leadership, lecturer performance, organizational culture, and competitiveness of Islamic Higher Education. The whole questionnaire used in this study was compiled by researchers based on the opinions of previous researchers who form the basis of this study. The questionnaire about visionary leadership was organized into 12 questions that would measure visionary leadership in universities. This questionnaire was compiled based on the views of previous experts as follows: Goethals et al. [11]; Whitehurst [12]; Taylor, Cornelius, \& Colvin [19]; Westley \& Mintzberg [9]. Questionnaire on lecturer performance was compiled based on the views of Ahmad \& Rashid [18]; Elliott [56]; Mather \& Seifert [57]; Polnaya et al. [58]; Taylor $\&$ Tyler [59]. The lecturer performance questionnaire was organized into 28 questions. The academic culture questionnaire was arranged into 22 items in measuring the condition of academic culture in Islamic universities in East Java, Indonesia. This questionnaire was developed based on the opinion of experts as follows: Ali, Sharma, \& Zaman [60]; Bass, Sergiovanni, \& Corbally [61]; EFA [62]; Freire \& Branco [63]; Prasad \& Jain [64]; Shen \& Tian [25]; Smith [26]. Questionnaire on the competitiveness of Islamic Higher Education was compiled into 8 question points based on the opinions of experts as follows: Boniface [65]; O’Regan \& Ghobadian [66]; Wilson \& Campbell [33]; Zhang, Zhao, \& Lecun [67]; Sagala [30]; Muhardi [32].

\section{Reliability and Validity of the Instrument}

The validity test of the visionary leadership instrument was sought by correlating the item scores with the overall scores showing the acquisition of the rxy correlation coefficient between 0.3661 to 0.8419 . While the significance level of 0.05 with the number of cases as many as 30 cases obtained $r$ table number of 0.239 . Of the 12 questions contained in the visionary leadership questionnaire, it was shown that all questions had a correlation coefficient value above $r$ table (0.239). In addition, the p-value (probability) is smaller than 0.05 , so all questions about visionary leadership are valid and can be used as research instruments. The overall results of the instrument validity test on visionary leadership can be seen in the following table: 
Prim Masrokan Mutohar et al; J Adv Educ Philos, Feb 2020; 4(2): 29-45

Table-2: The validity of Questionnaire Items on Visionary Leadership

\begin{tabular}{|l|l|l|l|l|l|}
\hline \multicolumn{5}{|c|}{ Item-Total Statistics } \\
\hline & $\begin{array}{l}\text { Scale Mean if } \\
\text { Item Deleted }\end{array}$ & $\begin{array}{l}\text { Scale Variance } \\
\text { if Item Deleted }\end{array}$ & $\begin{array}{l}\text { Corrected Item- } \\
\text { Total Correlation }\end{array}$ & $\begin{array}{l}\text { Squared Multiple } \\
\text { Correlation }\end{array}$ & $\begin{array}{l}\text { Cronbach's Alpha } \\
\text { if Item Deleted }\end{array}$ \\
\hline Item_1 & 38.1667 & 63.178 & .631 & .797 & .923 \\
\hline Item_2 & 38.4000 & 60.317 & .745 & .708 & .919 \\
\hline Item_3 & 38.2000 & 60.579 & .846 & .884 & .914 \\
\hline Item_4 & 38.2667 & 60.064 & .793 & .764 & .916 \\
\hline Item_5 & 37.9000 & 63.266 & .787 & .733 & .918 \\
\hline Item_6 & 37.9667 & 62.516 & .660 & .822 & .922 \\
\hline Item_7 & 38.1667 & 62.213 & .759 & .785 & .918 \\
\hline Item_8 & 38.1333 & 63.775 & .591 & .591 & .925 \\
\hline Item_9 & 37.9667 & 62.585 & .656 & .644 & .922 \\
\hline Item_10 & 38.3000 & 66.010 & .587 & .770 & .925 \\
\hline Item_11 & 38.1667 & 65.661 & .538 & .538 & .927 \\
\hline Item_12 & 38.3333 & 64.092 & .710 & .762 & .920 \\
\hline
\end{tabular}

The validity test of the teacher's performance instrument is sought by correlating the score of the item with the overall score showing the acquisition of the rxy correlation coefficient between 0.3100 to 0.8325 . While the significance level of 0.05 with the number of cases as many as 30 cases obtained $r$ table number of 0.239 . From the 28 questions contained in the lecturer performance questionnaire, it was shown that all questions had a correlation coefficient value above $r$ table (0.239). In addition, the p-value (probability) is smaller than 0.05 , then all questions about the performance of lecturers are declared valid. The overall results of the instrument validity test on the performance of lecturers can be seen in the following table:

Table-3: Validity Items of Lecturer Performance Questionnaire

\begin{tabular}{|l|l|l|l|l|l|}
\hline Item-Total Statistics & $\begin{array}{l}\text { Scale Mean if } \\
\text { Item Deleted }\end{array}$ & $\begin{array}{l}\text { Scale Variance } \\
\text { if Item Deleted }\end{array}$ & $\begin{array}{l}\text { Corrected Item- } \\
\text { Total Correlation }\end{array}$ & $\begin{array}{l}\text { Squared } \\
\text { Multiple } \\
\text { Correlation }\end{array}$ & $\begin{array}{l}\text { Cronbach's } \\
\text { Alpha if } \\
\text { Item Deleted }\end{array}$ \\
\hline Item_1 & 103.9333 & 168.133 & .314 &. & .912 \\
\hline Item_2 & 104.1667 & 164.557 & .409 &. & .910 \\
\hline Item_3 & 103.9667 & 163.895 & .503 &. & .908 \\
\hline Item_4 & 104.0333 & 158.792 & .648 &. & .905 \\
\hline Item_5 & 103.6667 & 164.644 & .566 &. & .907 \\
\hline Item_6 & 103.7333 & 160.271 & .615 &. & .906 \\
\hline Item_7 & 103.9333 & 168.271 & .337 & .911 \\
\hline Item_8 & 103.9000 & 164.162 & .471 &. & .909 \\
\hline Item_9 & 103.7333 & 164.961 & .429 &. & .910 \\
\hline Item_10 & 104.0667 & 168.892 & .375 &. & .910 \\
\hline Item_11 & 103.3333 & 166.299 & .516 &. & .908 \\
\hline Item_12 & 103.2667 & 168.409 & .479 &. & .909 \\
\hline Item_13 & 103.3333 & 165.747 & .544 &. & .907 \\
\hline Item_14 & 103.1667 & 162.557 & .678 &. & .905 \\
\hline Item_15 & 103.5667 & 162.116 & .620 &. & .906 \\
\hline Item_16 & 103.2000 & 165.476 & .577 &. & .907 \\
\hline Item_17 & 103.4000 & 166.662 & .495 &. & .908 \\
\hline Item_18 & 103.6667 & 164.920 & .524 &. & .908 \\
\hline Item_19 & 103.3000 & 168.562 & .316 & .907 \\
\hline Item_20 & 103.3667 & 168.930 & .330 &. & .911 \\
\hline Item_21 & 103.3333 & 166.299 & .516 &. & .908 \\
\hline Item_22 & 103.2667 & 168.409 & .479 &. & .909 \\
\hline Item_23 & 103.8000 & 166.579 & .455 &. & .909 \\
\hline Item_24 & 103.3333 & 166.299 & .516 &. &. \\
\hline Item_25 & 103.2667 & 168.409 & .479 &. &. \\
\hline Item_26 & 103.3333 & 165.747 & .544 & .678 &. \\
\hline Item_27 & 103.1667 & 162.557 & .620 &. &. \\
\hline Item_28 & 103.5667 & 162.116 & &. &. \\
\hline & & &. &. \\
\hline
\end{tabular}


Prim Masrokan Mutohar et al; J Adv Educ Philos, Feb 2020; 4(2): 29-45

The validity test of academic, cultural instruments is sought by correlating the item scores with the overall scores showing the acquisition of the rxy correlation coefficient between 0.3972 and 0.7801 . While the significance level of 0.05 with the number of cases as many as 30 cases obtained $r$ table number of 0.239 . Of the 22 questions contained in the organizational culture,the questionnaire showed that all questions had a correlation coefficient value above $r$ table (0.239). In addition, the p-value (probability) is smaller than 0.05 , so all items about the organizational culture of Islamic Higher Education are declared valid. The overall results of the instrument validity test on academic culture can be seen in the following table:

Table-4: Validity Items of the Academic Cultural Questionnaire Islamic Higher Education

\begin{tabular}{|l|l|l|l|l|l|}
\hline Item-Total Statistics & $\begin{array}{l}\text { Scale Mean if } \\
\text { Item Deleted }\end{array}$ & $\begin{array}{l}\text { Scale Variance } \\
\text { if Item Deleted }\end{array}$ & $\begin{array}{l}\text { Corrected } \\
\text { Item-Total } \\
\text { Correlation }\end{array}$ & $\begin{array}{l}\text { Squared } \\
\text { Multiple } \\
\text { Correlation }\end{array}$ & $\begin{array}{l}\text { Cronbach's } \\
\text { Alpha if Item } \\
\text { Deleted }\end{array}$ \\
\hline Item_1 & 84.9333 & 137.651 & .588 &. & .941 \\
\hline Item_2 & 84.8667 & 139.775 & .550 &. & .941 \\
\hline Item_3 & 84.9333 & 136.202 & .671 &. & .940 \\
\hline Item_4 & 84.7667 & 135.426 & .684 &. & .939 \\
\hline Item_5 & 85.1667 & 133.316 & .709 &. & .939 \\
\hline Item_6 & 84.8000 & 137.338 & .627 &. & .940 \\
\hline Item_7 & 85.0000 & 135.586 & .703 &. & .939 \\
\hline Item_8 & 84.9333 & 137.651 & .588 &. & .941 \\
\hline Item_9 & 84.8667 & 139.775 & .550 &. & .941 \\
\hline Item_10 & 84.9333 & 136.202 & .671 &. & .940 \\
\hline Item_11 & 84.7667 & 135.426 & .684 &. & .939 \\
\hline Item_12 & 85.1667 & 133.316 & .709 &. & .939 \\
\hline Item_13 & 84.8000 & 137.338 & .627 &. & .940 \\
\hline Item_14 & 85.0000 & 135.586 & .703 &. & .939 \\
\hline Item_15 & 85.2667 & 135.030 & .660 &. & .940 \\
\hline Item_16 & 84.9000 & 134.576 & .611 &. & .941 \\
\hline Item_17 & 84.9667 & 137.137 & .536 &. & .942 \\
\hline Item_18 & 84.8000 & 137.338 & .627 &. & .940 \\
\hline Item_19 & 85.0000 & 135.586 & .703 &. & .939 \\
\hline Item_20 & 85.2667 & 135.030 & .660 &. & .940 \\
\hline Item_21 & 84.9000 & 134.576 & .611 &. & .942 \\
\hline Item_22 & 84.9667 & 137.137 & .536 &. & \\
\hline
\end{tabular}

The validity test of the Islamic Higher Education competitiveness instrument is sought by correlating the item scores with the overall scores showing the acquisition of the rxy correlation coefficient between 0.3245 to 0.7935 . While the significance level of 0.05 with the number of cases as many as 30 cases obtained $r$ table number of 0.239 . From the 8 questions contained in the lecturer performance questionnaire, it was shown that all questions had a correlation coefficient value above $r$ table (0.239). In addition, the p-value (probability) is smaller than 0.05 , then all questions about the competitiveness of Islamic Higher Education are declared valid. The overall results of the instrument validity test on Islamic Higher Education competitiveness can be seen in the following table:

Table-5: The validity of Islamic Higher Education Competitive Questionnaire Item

\begin{tabular}{|c|c|c|c|c|c|}
\hline \multicolumn{6}{|c|}{ Item-Total Statistics } \\
\hline & $\begin{array}{l}\text { Scale Mean if } \\
\text { Item Deleted }\end{array}$ & $\begin{array}{l}\text { Scale Variance } \\
\text { if Item Deleted }\end{array}$ & $\begin{array}{l}\text { Corrected } \\
\text { Item-Total } \\
\text { Correlation }\end{array}$ & $\begin{array}{c}\text { Squared } \\
\text { Multiple } \\
\text { Correlation }\end{array}$ & $\begin{array}{l}\text { Cronbach's } \\
\text { Alpha if Item } \\
\text { Deleted }\end{array}$ \\
\hline Item_1 & 28.2000 & 16.166 & .531 & .604 & .839 \\
\hline Item_2 & 28.1333 & 16.671 & .539 & .375 & .839 \\
\hline Item_3 & 28.2000 & 16.303 & .507 & .451 & .842 \\
\hline Item_4 & 28.0333 & 15.206 & .668 & .621 & .823 \\
\hline Item_5 & 28.4333 & 14.668 & .662 & .543 & .823 \\
\hline Item_6 & 28.0667 & 16.064 & .572 & .436 & .835 \\
\hline Item_7 & 28.2667 & 15.651 & .620 & .459 & .829 \\
\hline Item_8 & 28.5333 & 15.223 & .613 & .637 & .830 \\
\hline
\end{tabular}




\section{Instrument Reliability Test}

The instrument reliability test in this study used the Alpha Cronbach formula [48, 53]. The reliability coefficient with the calculation obtained based on the formula is then interpreted with predetermined criteria. The instrument is declared reliable if it has a reliability coefficient value as low as 0.70 [68]. Anastasi [69] and Convey and Chwalek [70] stated that an instrument is considered reliable if it has a reliability coefficient of 0.80 and above. Then the instrument reliability level categories are stated in detail by Balian [71] as follows: (a) $0.00-0.79=$ not reliable, (b) $0.80-0.84=$ sufficiently reliable, (c) $0,85-0.89=$ reliable high, (d) $0.90-1.00=$ very high reliable. Based on the opinion of the experts mentioned above, for the purposes of this study, it was determined that the research instrument would be considered reliable if it had a reliability coefficient value of 0.80 and above [69, 70].

The results of the analysis of visionary leadership instruments, service excellence, lecturer performance, organizational culture, Islamic Higher Education quality, and Islamic Higher Education Competitiveness can be seen in the following table:

Table-6: Research Instrument Reliability

\begin{tabular}{|l|l|l|l|}
\hline \multirow{2}{*}{ Variable } & \multicolumn{3}{c|}{ Questionnaire Reliability } \\
\cline { 2 - 4 } & Number of Instrument Points & Alpha Cronbach & Information \\
\hline Visionary Leadership & 16 & 0,9342 & Reliable \\
\hline Lecturer Performance & 28 & 0,9264 & Reliable \\
\hline Academic Culture & 22 & 0,9139 & Reliable \\
\hline Islamic Higher Education Competitiveness & 8 & 0,9450 & Reliable \\
\hline
\end{tabular}

Based on table 3.10 about the results of the analysis of the reliability of the research instrument shows that the instruments related to visionary leadership variables have a very satisfactory level of reliability (0.9342), lecturer performance of 0.9264 , academic culture of 0.9139, Islamic Higher Education competitiveness of 0.9197, and Islamic Higher Education competitiveness of 0.9450 , which means that all of these variables have a very satisfactory level of reliability (excellent).

Based on the reliability test of the visionary leadership variables, service excellence, lecturer performance, organizational culture, Islamic Higher Education quality, and Islamic Higher Education competitiveness are said to be reliable, because the five variables have a correlation coefficient greater than 0.90 which indicates the level of reliability is very satisfactory (excellent). So all the instruments that have been prepared are suitable to be used as a data mining tool in this study.

\section{DATA COLLECTION PROCEDURES}

The research data collection was carried out in three stages. The first stage is getting information about the number and composition of students of Islamic Higher Education Tulungagung, Jember, and Madura to determine the population and research sample. Data collection was carried out through documentation studies at each tertiary institution. The second step is collecting data for the trial of the instrument. A trial was conducted on some Tulungagung students who were included in the study population but were not sampled. The third stage is collecting data in the context of actual research through questionnaires. The questionnaire is equipped with explanations and filling instructions to guide the respondent.

\section{DATA ANALYSIS PROCESS}

The data analysis process used in this research is to use descriptive analysis techniques and path analysis techniques. Both of these data analysis techniques can be given the following explanation:

\section{Descriptive Analysis Techniques}

Descriptive analysis techniques are used to describe the condition of each research variable based on data and empirical facts in the field. In other words, as a way to express a picture of the status or existence of visionary leadership variables, service excellence, lecturer performance, academic culture, quality, and competitiveness of Islamic Higher Education. The descriptive analysis techniques used in this study are the mean, median, mode, and percentage $[72,53]$.

\section{Path Analysis Techniques}

Based on the conceptual framework and research design, this study uses a path analysis model. Path analysis in this study can be used to predict or estimate the magnitude of the value of the coefficient of direct or indirect relationships between all variables in the study $[73,52,74,75]$. Path analysis will be carried out with three stages of analysis, namely: (1) the path of the relationship between visionary leadership and lecturer performance, (2) the path of relationship between visionary leadership and lecturer performance with academic culture, (3) the path of relationship between visionary leadership, lecturer performance, and academic culture with Islamic Higher Education competitiveness.

\section{RESULTS}

The quality and competitiveness of Islamic tertiary institutions in Indonesia must be improved in a 
Prim Masrokan Mutohar et al; J Adv Educ Philos, Feb 2020; 4(2): 29-45

sustainable manner in order to be able to realize highquality education and demand by the community. So that this can be realized well, it is necessary to pay attention and improve the conditions of leadership, lecturer performance, and academic culture in order to be able to create quality and competitiveness of Islamic tertiary institutions. The results of the descriptive analysis of these variables can be explained in the form of a table as follows:

Table-7: Results of Descriptive Analysis of Research Variables

\begin{tabular}{|c|c|c|c|c|c|}
\hline \multicolumn{6}{|c|}{ Statistics } \\
\hline & & Visionary Leadership & Lecture Performance & Academic Culture & Competitiveness \\
\hline \multirow[t]{2}{*}{$\mathrm{N}$} & Valid & 1135 & 1135 & 1135 & 1135 \\
\hline & Missing & 0 & 0 & 0 & 0 \\
\hline \multicolumn{2}{|c|}{ Mean } & 64.0767 & 168.8308 & 88.8696 & 35.0264 \\
\hline \multicolumn{2}{|c|}{ Median } & 64.0000 & 169.0000 & 90.0000 & 35.0000 \\
\hline \multicolumn{2}{|c|}{ Mode } & 55.00 & 170.00 & 92.00 & 35.00 \\
\hline \multicolumn{2}{|c|}{ Minimum } & 39.00 & 139.00 & 65.00 & 29.00 \\
\hline \multicolumn{2}{|c|}{ Maximum } & 80.00 & 192.00 & 108.00 & 40.00 \\
\hline
\end{tabular}

The results of this descriptive analysis were carried out based on 1135 respondents who had answered the research questionnaire correctly in accordance with their understanding, knowledge, and perception of the variables of this study. The analysis activity continued to find out the frequency level and percentage of each study variable by making class intervals based on the highest score minus the lowest score and divided by the number of class intervals.
Determination of the class interval and percentage produced in this study can be given an explanation as follows:

\section{Visionary Leadership in Indonesian Islamic Higher Education}

The results of the analysis of Visionary Leadership variables in Islamic Higher Education in Indonesia can be explained as follows:

Table-8: Frequency and Percentage Distribution of Visionary Leadership in Indonesian Islamic Higher Education

\begin{tabular}{|c|c|c|c|c|}
\hline \multicolumn{5}{|c|}{ Visionary Leadership } \\
\hline Number & Score & Frequency & Percentage & Classification \\
\hline 1 & $71-80$ & 317 & 27,9 & Very good \\
\hline 2 & $63-70$ & 339 & 29,9 & Good \\
\hline 3 & $55-62$ & 318 & 28 & Passably \\
\hline 4 & $47-54$ & 116 & 10,2 & Low \\
\hline 5 & $39-46$ & 45 & 4 & Not good \\
\hline \multicolumn{7}{|c|}{ Total } & 1135 & 100 & \\
\hline
\end{tabular}

The results of the descriptive analysis show that the condition of the visionary leadership variable has a mean of 64.0767 , a median of 64.0000 , and a mode of 55.00. The results of this analysis indicate that the visionary leadership conditions of leaders of Islamic tertiary institutions in Indonesia are in good condition. This is also supported by the results of the percentage analysis which shows right conditions with a percentage of $29.9 \%$ or as many as 339 respondents gave an assessment that the visionary leadership implemented by leaders of Islamic tertiary institutions is in good condition, followed by quite good conditions as much as $28 \%$, excellent, $27.9 \%$, not good $10.2 \%$, and not good 4\%. This shows that there is still a need for guidance and improvement of leadership competencies possessed by leaders of state Islamic religious institutes of higher education in Indonesia so that they can genuinely improve the quality and competitiveness of institutions.

\section{Lecturer Performance in Indonesian Islamic Higher Education}

The results of the analysis of the performance of lecturers in Islamic Higher Education in Indonesia can be explained as follows:

Table-9: Distribution of Frequency of Lecture Performance of Islamic Higher Education in Indonesia

\begin{tabular}{|c|c|c|c|c|}
\hline \multicolumn{5}{|c|}{ Lecture Performance } \\
\hline Number & Score & Frequency & Percentage & Classification \\
\hline 1 & $183-193$ & 77 & 6,8 & Very good \\
\hline 2 & $172-182$ & 513 & 45,2 & Good \\
\hline 3 & $161-171$ & 345 & 30,4 & Passably \\
\hline 4 & $150-160$ & 183 & 16,1 & Low \\
\hline 5 & $139-146$ & 17 & 1,5 & Not good \\
\hline \multicolumn{6}{r}{ Total } & 1135 & 100 & \\
\hline
\end{tabular}


Descriptive analysis results show that the condition of the variable performance of lecturers of Islamic Higher Education in Indonesia obtained a mean value of 168.8 , a median of 169 , and a mode of 170 . The results of this analysis indicate that the performance of the lecturer is in good condition, as well as the results of the analysis of presentations also indicate the conditions both with a percentage of $45.2 \%$ or as many as 513 respondents gave an assessment that the performance of Islamic Higher Education lecturers in Indonesia is in good condition. This condition was followed by the acquisition of a percentage of $30.4 \%$ or was in a reasonably good condition, $16.1 \%$ were not pleasant, $6.8 \%$ were excellent, $1.5 \%$ and $1.5 \%$ were not good. This shows that there are still $26 \%$ of the performance of lecturers who need ongoing coaching to be able to show excellent performance, so they can support the formation of academic culture and institutional competitiveness that occurs in this global era.

\section{Academic Culture in Indonesian Islamic Higher Education}

The results of the analysis of academic culture in Islamic Higher Education in Indonesia can be explained as follows:

Table-10: Distribution of Academic Culture Frequencies at Islamic Higher Education
\begin{tabular}{|c|c|c|c|c|}
\hline \multicolumn{5}{|c|}{ Academic Culture } \\
\hline Number & Score & Frequency & Percentage & Classification \\
\hline 1 & $101-109$ & 88 & 7,8 & Very good \\
\hline 2 & $92-100$ & 402 & 35,4 & Good \\
\hline 3 & $83-91$ & 371 & 32,7 & Passably \\
\hline 4 & $74-82$ & 233 & 20,5 & Low \\
\hline 5 & $65-73$ & 41 & 3,6 & Not good \\
\hline
\end{tabular}

Based on the results of descriptive analysis shows that the condition of the academic culture variable of the Indonesian Islamic High School has a mean value of 88.8696 , a median of 90 , and a mode of 92 , this shows that the academic culture variable is in good condition and the value that often appears is also in a good condition. This is also supported by the results of the percentage analysis which shows that the academic culture variable obtained a percentage value of $35.4 \%$ or as many as 402 respondents gave an assessment that the academic culture in the Indonesian Islamic College is in good condition. This condition is followed by the acquisition of a percentage of $32.7 \%$ or is in a reasonably good condition, $20.5 \%$ is not right,
$7.8 \%$ is excellent, and $3.6 \%$ is not good. This shows that there are still $56.8 \%$ of respondents who have the perception that academic culture needs continuous improvement to be able to show a good, positive, and dynamic academic culture so that it can support the formation of institutional competitiveness in the global era.

\section{Competitiveness of Islamic Higher Education in Indonesia}

The results of the analysis of the competitiveness of Islamic Higher Education variables in Indonesia can be explained as follows:

Table-11: Frequency Distribution of Islamic Higher Education Competitiveness in Indonesia

\begin{tabular}{|c|c|c|c|c|}
\hline \multicolumn{5}{|c|}{ Competitiveness of Higher Education } \\
\hline Number & Score & Frequency & Percenta & Classification \\
\hline 1 & $38-40$ & 129 & 11,4 & Very good \\
\hline 2 & $35-37$ & 543 & 47,8 & Good \\
\hline 3 & $33-34$ & 336 & 29,6 & Passably \\
\hline 4 & $31-32$ & 119 & 10,5 & Low \\
\hline 5 & $29-30$ & 8 & 0,7 & Not good \\
\hline & Total & 1135 & 100 & \\
\hline
\end{tabular}

Based on the results of the descriptive analysis shows that the condition of the competitiveness variable of Islamic Higher Education in Indonesia is in excellent condition with a mean value of 35.0264 , a median of 35 , and a mode of 35 . The percentage value obtained by $47.8 \%$ or as many as 543 respondents gave an assessment that the competitiveness of Islamic Higher
Education in Indonesia is in good condition. This condition was followed by the acquisition of a percentage of $29.6 \%$ or was in a reasonably good condition, $11.4 \%$ was excellent, $10.5 \%$ was not good, and $0.7 \%$ was not good. This shows that there are still $40.8 \%$ of respondents who have the perception that the competitiveness of Islamic Higher Education needs 
continuous improvement in order to be able to demonstrate good, healthy, dynamic, and competitive competitiveness so that they can meet the demands and expectations of the community and education stakeholders.

The path analysis used in this research hypothesis test is intended to determine the relationship between variables, both direct and indirect relationships. Hypothesis testing is carried out in stages in accordance with the model developed in this study which consists of three relationship paths that can be given the following explanation:

\section{Contribution of Visionary Leadership to Lecturer Performance}

The results of the analysis of the relationship between stage 1 can be explained that the coefficient of direct visionary leadership (X1) and academic culture (X2) is depicted with a coefficient b of 0.377 , at the value of 7.219, and $p$ (sig-t) of 0,000 . This means that $p$ is smaller than the 0.05 significance level. The results of this analysis show that the null hypothesis that there is no direct relationship between visionary leadership and academic culture is rejected, and it can be concluded that there is a significant direct relationship between visionary leadership and academic culture at the Indonesian State Islamic Institute. The academic coefficient of the dependent variable academic culture $(\mathrm{P} 2 \mathrm{v})$ on this pathway is 0.926 . This relationship path model can be seen in the picture as follows:

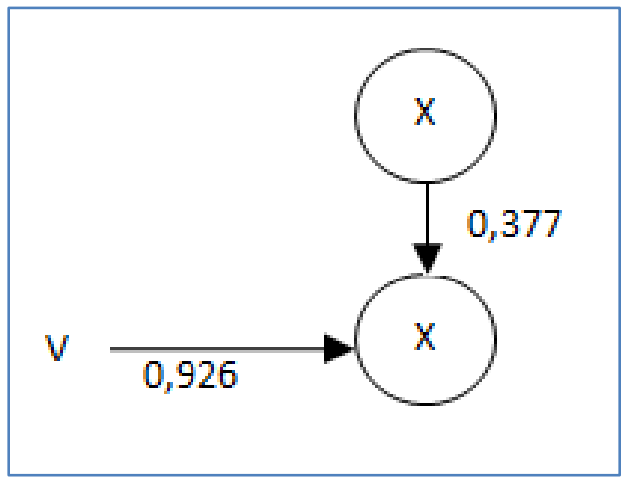

Fig-2: Path Hypothetic Model The relationship between visionary leadership and academic culture

\section{Contribution of Visionary Leadership and Lecturer Performance to Academic Culture}

The pathway model of the Visionary Leadership and Lecturer Performance to Academic Culture that will be tested in this study is hypothesized as follows: (1) There is no significant direct relationship of visionary leadership (X1) with academic culture (X3), (2) there is no direct relationship significant between lecturer performance (X2) and academic culture (X3), (3) there is no significant indirect relationship between visionary leadership (X1) and academic culture (X3) through lecturer performance (X2). Based on the results of the analysis of the stage 2 relationship path, it can be explained that the coefficient of the direct relationship between visionary leadership (X1) and academic culture (X3) is depicted with a coefficient $b$ of 0.266 , at the value of 4.993 , and $p$ (sigt) of 0,000 . This means that $p$ is smaller than the significance level of 0.05 . Based on the 0.05 significance level, the null hypothesis, which states there is no significant direct relationship between visionary leadership and academic culture, is rejected. Thus, it can be concluded that there is a significant direct relationship between visionary leadership and academic culture.

The coefficient of the direct relationship between lecturer performance (X2) and academic culture (X3) is depicted with a coefficient b of 0.319 , at the value of 5.998, and $\mathrm{p}$ (sig-t) of 0,000 . This means that $\mathrm{p}$ is smaller than the significance level of 0.05 . Based on the 0.05 significance level, it means that the null hypothesis, which states that there is no significant direct relationship between visionary leadership and academic culture, is rejected. Thus, it can be concluded that there is a significant direct relationship between visionary leadership and academic culture.

The indirect relationship between visionary leadership (X1) and academic culture (X3) through lecturer performance (X2) is calculated by multiplying P21 with P32 with the following results: P21 x P32 = $0.377 \times 0.319=0.120$. The academic coefficient of the academic culture-dependent variable $(\mathrm{P} 3 \mathrm{u})$ in the stage II relationship pathway obtained a value of 0.873 . The results of the analysis of this relationship path model can be seen in the picture as follows:

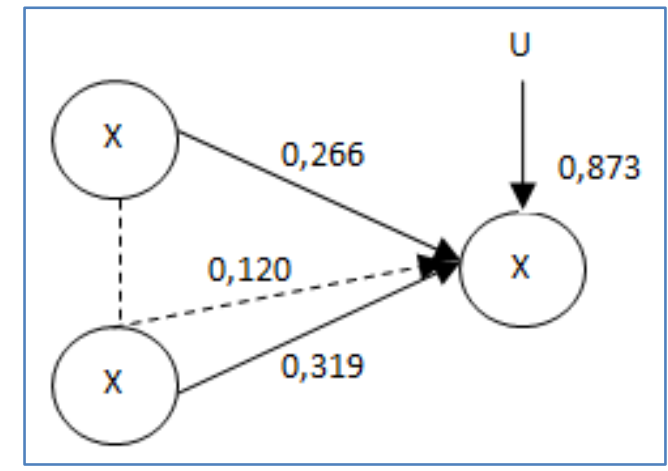

Fig-3: Correlation Coefficients on the Model of Relationships among Phase II Variables

Contribution of Visionary Leadership, Lecturer Performance, and Academic Culture to Islamic Higher Education Competitiveness

Based on the results of the analysis of the block III relationship path, it can be seen that the coefficient of the direct relationship between visionary leadership (X1) with the competitiveness of Islamic Higher Education (Y) is illustrated with a coefficient $b$ of 0.142 , $t$ value of 2.630 , and $p$ (sig-t) of 0.009 . This means that $\mathrm{p}$ is smaller than the significance level of 0.05 . Based on the 0.05 significance level, it means that the null hypothesis, which states there is no significant 
direct relationship between visionary leadership and competitiveness, is rejected. Thus, it can be concluded that there is a significant direct relationship between visionary leadership and Islamic Higher Education competitiveness.

The coefficient of the direct relationship between lecturer performance (X2) and the competitiveness of Islamic Higher Education (Y) is illustrated by the coefficient $b$ of $0.192, t$ value of 3.318, and $\mathrm{p}$ (sig-t) of 0.001 . This means that $\mathrm{p}$ is smaller than the significance level of 0.05 . Based on the 0.05 significance level, it means that the null hypothesis, which states there is no significant direct relationship between lecturer performances with Islamic Higher Education competitiveness, is rejected. Thus, it can be concluded that there is a significant direct relationship between lecturer performances with Islamic Higher Education competitiveness.

The coefficient of a direct relationship between academic culture (X3) and the competitiveness of Islamic Higher Education (Y) is depicted with a coefficient $b$ of 0.192 , at the value of 3.434 , and $p$ (sigt) of 0.001 . This means that $\mathrm{p}$ is smaller than the significance level of 0.05 . Based on the 0.05 significance level, it means that the null hypothesis, which states there is no significant direct relationship between academic culture and Islamic Higher Education competitiveness, is rejected. Thus, it can be concluded that there is a significant direct relationship between academic culture and Islamic Higher Education competitiveness.

The coefficient of the indirect relationship between visionary leadership (X1) and Islamic Higher Education (Y) competitiveness through lecturer performance (X2) is calculated manually by multiplying P21 and Py2 with the following results: $\mathrm{P} 21 \times \mathrm{Py} 2=0.417 \times 0.282=0.117$. Thus the path coefficient value of 0.117 is obtained; this value indicates more significant than the significance level of
0.05 , meaning that the null hypothesis states that there is no significant indirect relationship between visionary leadership and Islamic Higher Education competitiveness through the performance of Islamic Higher Education lecturers in rejecting. Thus it can be concluded that there is a significant indirect relationship between visionary leadership and Islamic Higher Education competitiveness through lecturer performance.

The coefficient of the indirect relationship between visionary leadership (X1) and the competitiveness of Islamic Higher Education (Y) through academic culture (X3) is calculated manually by multiplying P31 and Py3 with the following results: $\mathrm{P} 31 \times \mathrm{Py} 3=0.319 \times 0.192=0.061$. Thus the path coefficient value of 0.061 was obtained; this value indicates more significant than the significance level of 0.05 , meaning the null hypothesis, which states there is no significant indirect relationship between visionary leadership with Islamic Higher Education competitiveness through academic culture, is rejected. Thus it can be concluded that there is a significant indirect relationship between visionary leadership and Islamic Higher Education competitiveness through academic culture.

The coefficient of the indirect relationship between lecturer performance (X2) and the competitiveness of (Y) through academic culture (X3) is calculated manually by multiplying P32 and Py3 with the following results: P32 $\times$ Py3 $=0.335 \times 0.194=$ 0.064 . Thus the path coefficient value of 0.065 was obtained; this value indicates more significant than the significance level of 0.05 , meaning the null hypothesis, which states there is no significant indirect relationship between lecturer performances with competitiveness through academic culture, is rejected. Thus it can be concluded that there is a significant indirect relationship between lecturer performances with competitiveness through academic culture.

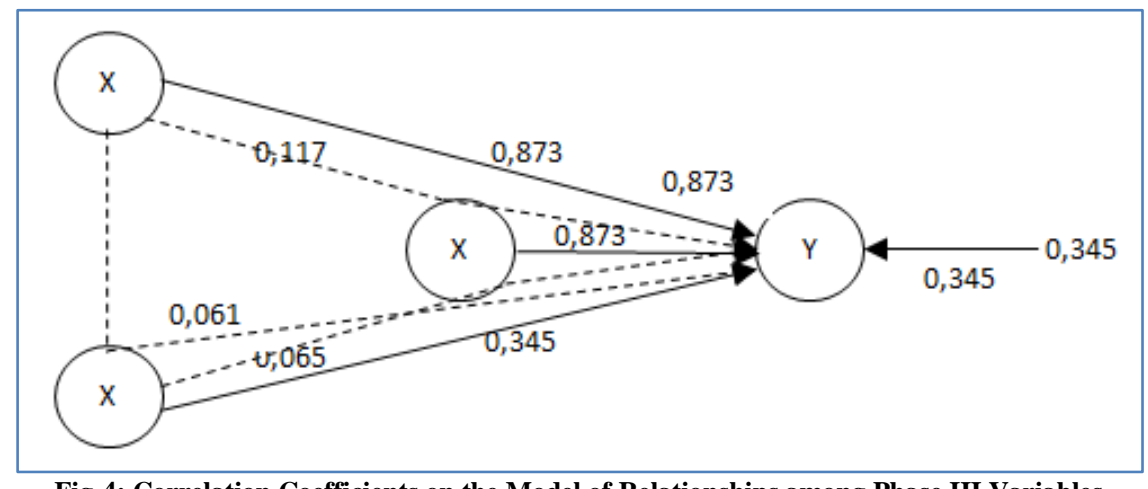

Fig-4: Correlation Coefficients on the Model of Relationships among Phase III Variables

\section{DISCUSSIONS}

Quality education becomes more desirable by the community and education stakeholders because it is in accordance with the needs and expectations of the community. This condition requires an effort to improve the quality and competitiveness of education in the current global era. Efforts to improve the quality 
and competitiveness of education are carried out continuously in line with the development of science and technology. The results showed that visionary leadership has a direct influence on improving the quality and competitiveness of education. The findings of this study are supported by the results of research that explain that leadership style is a significant factor determining organizational success [8, 76, 77]. This is as suggested by Kim [78], which explains that "leaders have the ability to change organizations based on the vision of institutions that are oriented to the future, clarify the organization's vision, empower employees to have responsibilities in achieving the organization's vision." A visionary leader would you be willing to review submissions to this journal? The ship must be able to turn vision into action in order to be able to improve the performance of all existing personnel [76, $77,12]$. This leadership usually displays four different behaviors: ideal influence, inspirational motivation, intellectual stimulation, and individual judgment [41]. In short, the ideal influence of leaders is closely related to the behavior of leaders who show high standards of moral and ethical behavior. Leaders become confident, are held in high esteem, and act as strong role models for all members of the organization [20]. The ability to see opportunities owned by educational leaders can provide energy in articulating a vision that is able to motivate personnel in improving effective performance. Visionary leaders inspire academic civets in sharing their vision and empowering them to achieve it. Leaders are able to encourage and mobilize lecturers in increasing work productivity, presenting challenging new ideas, and various ways to solve problems in educational institutions.

Professional lecturers will show productive performance, so they can form a high academic culture and make the institution have high competitiveness. The research findings show that the performance of lecturers has a direct influence on the academic culture and competitiveness of the institution. Organizational performance influences organizational culture [79, 80, 81]. This condition indicates the need for efforts to be taken by educational institutions in improving lecturer performance. A productive and effective lecturer performance can improve the competitiveness of educational institutions because a distinctive academic culture will be formed, and student achievement will increase. Managers, funders, as well as stakeholders and consumers are very concerned about performance results [82]. Lecturer performance results are reflected in the learning outcomes or achievements achieved by students [83, 57, 84]. Effective lecturer performance will result in high learning achievement. Recognizing the importance of lecturer performance, lecturers must be empowered as much as possible, and efforts are also made to improve and improve the performance, including through coaching and training, as well as an assessment of lecturer performance objectively in order to increase lecturer productivity in the learning process
[78, 85, 86]. It must also be supported by quality management of institutions, quality and ready-made learning facilities and infrastructure, as well as high community participation in education $[21,91,9]$.

Leadership has a role in creating organizational reality and shaping organizational culture [21, 79, 87]. Organizational productivity includes the performance of lecturers that will be realized if supported by an influential academic culture and a conducive organizational climate. This shows that leadership applied by leaders will influence the formation of academic culture in universities. Organizational culture is one of the variables that determine the success of job implementation [79, 88, 80]. Gordon, et al. [42] research results show that influence organizational culture makes members more satisfied, motivated, and has a significant commitment to the organization. Likewise, Sergiovanni [87] found that an influential culture would increase the commitment, enthusiasm, and loyalty of members towards the organization. From these results, it can be concluded that the firm and positive academic culture of Islamic Higher Education in Indonesia will be able to empower lecturers and improve lecturer performance because lecturers have strong motivation, job satisfaction, and high commitment to the success of learning in higher education.

Visionary leadership, lecturer performance, and academic culture in universities have an influence on improving the quality and competitiveness of educational institutions. The better visionary leadership is applied in educational institutions, the better the performance of lecturers in tertiary institutions will contribute to the formation of academic culture and enhance the competitiveness of educational institutions in the global era. This finding shows that leaders in higher education are the key to making changes in the overall components of higher education. Leaders of educational institutions can act as agents of change, so the success and failure of the system depend on academic leaders because they have a direct or indirect contribution to the education system [89]. Leaders also have a positive influence on improving performance $[90,77]$. On the other hand, leadership also contributes to shaping organizational reality [41, 88]. Academic culture in universities also has a contribution to achieving the goals of the institution [60]. This shows that the leadership applied by leaders in educational institutions is very decisive on organizational performance, academic culture, quality, and competitiveness of educational institutions. Therefore, leaders must be able to carry out their leadership well and continuously improve their competence so that the quality and competitiveness of educational institutions can be improved in accordance with the needs and expectations of educational stakeholders. 


\section{CONCLUSION}

Visionary leadership found in universities has a significant contribution to improving the performance of lecturers, academic culture, and the competitiveness of universities both directly and indirectly. Visionary leadership becomes a decision that can be applied in predicting, seeing, and predicting based on data that can be accounted for to see the needs and opportunities that can be achieved in improving the quality and competitiveness of higher education. This leadership is the key to the success of higher education institutions in making changes and developments oriented to improving quality on an ongoing basis. Visionary leaders will be able to mobilize all human and nonhuman resources in educational organizations to jointly achieve educational goals. This leadership will also be able to inspire all members of the organization to think and act creatively and innovatively in carrying out their respective duties and responsibilities within the organizational system. The performance will be maximally improved so that it will form a reasonable and competitive academic culture in higher education institutions. A pleasant and conducive academic culture will be able to color organizations in higher education institutions so as to improve the quality and competitiveness of educational institutions. Increasing the quality and competitiveness will deliver higher education to the public and education stakeholders.

\section{REFERENCES}

1. Cetindere, A., Duran, C., \& Yetisen, M. S. (2015). The effects of total quality management on business performance: An application in the province of Kütahya. Procedia Economics and Finance. 5671(15)00366-4

2. Tikly, L., \& Barrett, A. M. (2011). Social justice, capabilities, and quality of education in lowincome countries. International Journal of Educational Development. https://doi.org/ 10.1016/j.ijedudev.2010.06.001

3. Mutohar, P.M., \& Masduki. (2018). Manajemen Strategik Pendidikan: Strategi Peningkatan Mutu dan Daya Saing Pendidikan Tinggi. Tulungagung: Cahaya Abadi

4. Ristekdikti. (2018). Era Revolusi Industri 4.0 Saatnya Generasi Millenial Menjadi Dosen Masa Depan.

5. Taylor, S. W., \& Alexander, M. E. (2006). Science, technology, and human factors in fire danger rating: The Canadian experience. International Journal of Wildland Fire. https://doi.org/10.1071/WF05021

6. Alma, B. (2009). Manajemen Pemasaran dan Pemasaran Jasa. Bandung: Alfabeta

7. Sallis, E. (2007). Total Quality Management in Education. Jogjakarta: Ircisod

8. Ismail, A., Shaik, A. R., Hishamuddin, Saludin, M. N., Al-Banna, M.H., \& Nordin, R. (2010). Relationship between Leaders and Followers as a
Predictor of Organizational Commitment and Organizational Commitment and Job Satisfaction. In the 5th National Human Resource Management Conference 2010.

9. Westley, F., \& Mintzberg, H. (1989). Visionary leadership and strategic management. Strategic Management Journal. https://doi.org/10.1002/smj.4250100704

10. Almog-Bareket, G. (2012). Visionary leadership in business schools: An institutional framework. Journal of Management Development. https://doi.org/10.1108/02621711211219086

11. Goethals, G., Sorenson, G., Burns, J., \& Kirkpatrick, S. A. (2012). Visionary Leadership Theory. In Encyclopedia of Leadership. https://doi.org/10.4135/9781412952392.n368

12. Mora-Whitehurst, R. (2013). The Relationship between Elementary Principals' Visionary Leadership and Students' Reading Performance. Educational Forum, 77(3), 315-328. https://doi.org/10.1080/00131725.2013.792897

13. Westley, K. E. (2011). Teacher quality and student achievement. Teacher Quality and Student Achievement.

14. Komariah, A., \& Triatna, C. (2005). Visionary Leadership Menuju Sekolah Efektif. Jakarta: Bumi Aksara.

15. Landy, F.J., \& Farr, J.L. (1983). The Measurement of Work Performance: Methods, Theory, and Applications. San Diego: Academic Press, Inc.

16. Baird, L. (1986). Management Performance. Toronto: John Wiley and Sons, Inc.

17. Cascio, W.F. (1995). Managing Human Resource Productivity, Quality of Work, Life, and Profit, 4th. Edition, NY. Mc. Graw Hill, Inc.

18. Ahmad, H., \& Rashid, T. (2016). Lecturer performance analysis using multiple classifiers. Journal of Computer Science. https://doi.org/10.3844/jcssp.2016.255.264

19. Taylor, E. S., \& Tyler, J. H. (2012). The effect of evaluation on teacher performance. American Economic https://doi.org/10.1257/aer.102.7.3628

20. Buil, I., Martínez, E., \& Matute, J. (2019). Transformational leadership and employee performance: The role of identification, engagement, and proactive personality. International Journal of Hospitality Management, 77(May), $\quad$ 64-75 https://doi.org/10.1016/j.ijhm.2018.06.014

21. Bureau, M. (2003). Teacher Performance Management. Education and Manpower Bureau.

22. Hoy, W.K., \& Miskel, C.G. (1987). Educational Administration, Theory, Research, and Practice. New York: Random House.

23. Jæger, M. M. (2011). Does cultural capital really affect academic achievement? New evidence from combined siblings and panel data. Sociology of Education, $\quad 84(4)$ 281-298. https://doi.org/10.1177/0038040711417010 
24. Rienties, B., Beausaert, S., Grohnert, T., Niemantsverdriet, S., \& Kommers, P. (2012). Understanding the academic performance of international students: The role of ethnicity, academic, and social integration. Higher Education. https://doi.org/10.1007/s10734-011-9468-1

25. Shen, X., \& Tian, X. (2012). Academic Culture and Campus Culture of Universities. Higher Education Studies. https://doi.org/10.5539/hes.v2n2p61

26. Smith, D. N. (2013). Academics, the "cultural third mission" and the BBC: forgotten histories of knowledge creation, transformation, and impact. Studies in Higher Education, 38(5), 663-677. https://doi.org/10.1080/03075079.2011.594502

27. Robbins, S.P. (1998). Organizational Behavior: Concepts, Controversies, and Application. Upper Saddle River, New Jersey: Prentice Hall, Inc.

28. Creemers, B.P.M., \& Reynolds, D. (2002). School Effectiveness and School Improvement to Effective School Improvement: Backgrounds, Theoretical Analysis, and Outline of the Empirical Study. Educational Research and Evaluation, 8(4), 343362.

29. Greenberg, J., \& Baron, R.A. (1995). Behavior in Organizations, Understanding and Managing the Human Side of Work. Englewood Cliffs, New Jersey: Prentice Hall, Inc.

30. Sagala, S (2010). Manajemen Strategik dalam Peningkatan Mutu Pendidikan, Bandung: Alfabeta

31. Permendiknas No. 41. (2007). Standar Proses Untuk Satuan Pendidikan Dasar dan Menengah. Jakarta: BSNP

32. Muhardi. (2007). Strategi Operasi: Untuk Keunggulan Bersaing. Yogyakarta: Graha Ilmu.

33. Wilson, J. P., \& Campbell, L. (2018). ISO 9001:2015: the evolution and convergence of quality management and knowledge management for competitive advantage. Total Quality Management and Business Excellence, 0(0), 1-16. https://doi.org/10.1080/14783363.2018. 1445965

34. Bencivenga, A. S., \& Elias, M. J. (2003). Leading schools of excellence in academics, character, and social-emotional development. Nass Bulletin, 87(637), 60-72.

35. El-Hariri, R. (2011). Pengaruh Perilaku Kepemimpinan Terhadap Kinerja Layanan Akademik Pegawai di Universitas Pendidikan Indonesia. Jurnal MANAJERIAL, 10(2), 32-41.

36. Alonderiene, R., \& Majauskaite, M. (2016). Leadership style and job satisfaction in higher education institutions. International Journal of Educational Management, 30(1), 140-164

37. Mondy, N. (1990). Training Program Development. New Jersey: Prentice Hall, Inc.

38. Yukl, G.A. (1989). Leadership in Organizational. Englewood Cliffs, New Jersey: Prentice Hall, Inc

39. Sergiovanni, T.J., \& Corbally, J.E. (1984). Leadership and organizational culture. Chicago: Univesity of Illinois Press.
40. Schein, Edgar H. (1985). Organizational Culture and Leadership, 1st Edition, San Francisco, CA, Jossey-Bass

41. Bass, B.M. (1985). Leadership and Performance beyond Expectation. New York : Academic Press

42. Gordon, J.R., Mondy, R.W., Sharplin, A., \& Premeaux, S.R. (1990). Management and Organizational Behavior. Boston: Allyn and Bacon. Boston: Allyn and Bacon.

43. Fieldman, D.C., \& Arnold, H.J. (1983). Managing Individual and Group Behavior in Organization. Singapore: McGraw-Hill Book Company.

44. Feldman, M., \& Schiller, L. R. (1983). Disorders of gastrointestinal motility associated with diabetes mellitus. Annals of Internal Medicine, 98(3), 378384.

45. Hanson, E.M. (1995). Educational Administration and Organizational Behavior. Newton, Massachusetts: Allyn and Bacon, Inc.

46. DeRoche, E.F. (1987). An Administrator's Guide for Evaluating Programs and Personnel: An Effective School Approach. Boston: Allyn and Bacon.

47. Gay, N.L., \& Berliner, D.C. (1990). Educational Research: Competencies for Analysis and Application. Toronto: Merril Publishing Company.

48. Ary, D., Jacobs, L. C., Razavieh. (1985). Introduction to Research in Education. New York: Holt, Rinehart.

49. Ardhana, W. (1987). Bacaan Pilihan dalam Metode Penelitian Pendidikan. Jakarta: PPLPTK. Ditjen. Dikti. Depdikbud.

50. Arikunto, S. (1998). Prosedur Penelitian Suatu Pendekatan Praktek. Rineka Cipta: Jakarta.

51. Kerlinger, F.N. (1985). Behavioral Research. New York: Holt Rinehart \& Winston

52. Cohen, J., \& Cohen, P. (1983). Applied Multiple Regression/Correlation Analysis for the Behavioral Science. London: Lawrence Erlbaum Associates Publisher.

53. Borg \& Gall. (2003). Education Research. New York: Allyn and Bacon.

54. Dalen, D.B.V. (1979). Understanding Educational Research an Introduction. New York:McGraw-Hill Book Company

55. Cohen, L., Manion, L., \& Morrison, K. (2007). Research Methods in Education (6th ed.). London, New York: Routllege Falmer

56. Elliott, K. (2015). Teacher performance appraisal: More about performance or development? Australian Journal of Teacher Education. https://doi.org/10.14221/ajte.2015v40n9.6

57. Mather, K., \& Seifert, R. (2011). Teacher, lecturer, or laborer? Performance management issues in education. Management in Education. https://doi.org/10.1177/0892020610388060

58. Polnaya, I., Nirwanto, N., \& Triatmanto, B. (2018). The evaluation of lecturer performance through soft skills, organizational culture, and 
compensation on the Private University of Ambon. Academy of Strategic Management Journal.

59. Taylor, C. M., Cornelius, C. J., \& Colvin, K. (2014). Visionary leadership and its relationship to organizational effectiveness. Leadership and Organization Development Journal. https://doi.org/10.1108/LODJ-10-2012-0130

60. Ali, N., Sharma, S., \& Zaman, A. (2016). School Culture and School Effectiveness: Secondary Schools in Pakistan. Malaysian Online Journal of Educational Management, 4(4), 50-65. https://doi.org/10.22452/mojem.vol4no4.4

61. Bass, B. M., Sergiovanni, T. J., \& Corbally, J. E. (1985). Leadership and Organizational Culture: New Perspectives on Administrative Theory and Practice. The Journal of Higher Education. https://doi.org/10.2307/1981221

62. EFA. (2016). The Effect Of Work Culture Pedagogic Competence and Work Commitment Toward Task Performance Teacher Vocational High School Bandar Lampung. Ilmiah Educational Management.

63. Freire, S. F. de C. D., \& Branco, A. U. (2019). Dynamics between self and culture in school: A dialogical and developmental perspective. Learning, Culture, and Social Interaction, 20(October 2017), 24-31. https://doi.org/10.1016/j.lcsi.2017.10.004

64. Prasad, S. P., \& Jain, G. K. (2011). A study of organizational culture and employees' commitment to Indian organizations. International Journal of Transformations in Business Management.

65. Boniface, C. M. (2011). Organizational culture as a driver of competitive advantage. Journal of Academic \& Business Ethics.

66. O'Regan, N., \& Ghobadian, A. (2005). The strategic planning process: A navigational tool for competitive advantage. International Journal of Process Management and Benchmarking, 1(1), 6381. https://doi.org/10.1504/IJPMB.2005.006112

67. Zhang, X., Zhao, J., \& Lecun, Y. (2015). Character-level convolutional networks for text classification. In Advances in Neural Information Processing Systems.

68. Gay, L.R., \& Diehl, P.L. (1990). Research Methods for Business and Management. New York: McMillan Publishing Company.

69. Anastasi, A. (1982). Psychological Testing (Fifth Edition). Amerika: Macmillan Publishing Co., Inc.

70. Convey, L., \& Chwalek, A.R. (1986). Completing a Dissertation in the Behavioral Sciences and Education. London: Jossey-Bass Publishers.

71. Balian, E.S. (1982). How to Design, Analyze, and Write Doctoral Research. New York: University Press of America, Inc.

72. Sugiyono. (2000). Metode Penelitian Bisnis, Bandung: CV Alfabeta.

73. Blalock, H. M. (1971). Social Statistics, London: McGraw-Hill Book Company.
74. Weisberg, R. W. (1988). Problem solving and creativity. The nature of creativity, 148-176.

75. Hasan, M.Z. (1995). Analisis Jalur. Makalah disajikan dalam Lokakarya Statistik dan Analisis Data Penelitian dengan Komputer Angkatan VII tahun 1995/1996. Lemlit IKIP Malang, Malang 30 Januari - 1 Maret 1996.

76. Kuswandi, Sundjoto, Noor, A., \& Purwanto. (2015). Effects of Transformational Leadership, Personal values, Job Satisfaction on Lecturer Performance. Journal of Arts, Science \& Commerce.

77. Liphadzi, M., Aigbavboa, C., \& Thwala, W. (2015). Relationship between Leadership Styles and Project Success in the South Africa Construction Industry. In Procedia Engineering. https://doi.org/10.1016/j.proeng.2015.10.091

78. Anggraeni, R. D. (2014). Increasing Lecturer Competence as the Quality Assurance of Lecturer Performance. Management Studies.

79. Handoko, Y., Setiawan, M., Surachman, \& Djumahir. (2010). Organizational Culture, Job Satisfaction, Organizational Commitment, the Effect on Lecturer Performance. International Journal of Business and Management Invention.

80. Sumarni, S. (2017). School Culture and School Performance. EDUKASI: Jurnal Penelitian Pendidikan Agama Dan Keagamaan. https://doi.org/10.32729/edukasi.v7i3.122

81. Ying, L. H., \& Ahmad, K. Z. B. (2009). The moderating effects of organizational culture on the relationships between leadership behavior and organizational commitment and between organizational commitment and job satisfaction and performance. Leadership and Organization Development https://doi.org/10.1108/01437730910927106

82. Steers, R.M., \& Porter, L.W. (1983). Motivation and Work Behaviour, New York: Academic Press.

83. Gül, H. (2010). Evaluation of lecturer performance depending on student perception in higher education. Egitim ve Bilim.

84. Samian, Y., \& Noor, N. M. (2012). Student's Perception of Good Lecturer based on Lecturer Performance Assessment. Procedia - Social and Behavioral Sciences. https://doi.org/ 10.1016/j.sbspro.2012.09.716

85. Kumaladewi, N., \& Sugiarti, Y. (2016). Design analysis of data warehouse for lecturer performance evaluation (Case study: Faculty of science and technology UIN Jakarta). In Proceedings of 2016 4th International Conference on Cyber and IT Service Management, CITSM 2016. https://doi.org/10.1109/CITSM.2016.7577531

86. Suryaman. (2018). Indonesian private university lecturer performance improvement model to improve sustainable organization performance. International Journal of Higher Education. https://doi.org/10.5430/ijhe.v7n1p59 
Prim Masrokan Mutohar et al; J Adv Educ Philos, Feb 2020; 4(2): 29-45

87. Sergiovanni, T.J. (2000). The Lifeworld of Leadership: Creating Culture, Community, and Personal Meaning in Our Schools. The Lifeworld of Leadership.

88. Sergiovanni, T. J. (2013). Leadership as pedagogy, capital development, and school effectiveness. In Educational Management: Major Themes in Education. https://doi.org/ 10.4324/9780203463383

89. Yan-Li, S., \& Hassan, D. (2018). Leadership behavior on job satisfaction in Malaysian national secondary schools: Motivation and hygiene satisfaction. Malaysian Online Journal of Educational Management, 6(3), 48-67. https://doi.org/10.22452/mojem.vol6no3.3

90. Koech, P. M., \& Namusonge, G. (2012). The Effect of Leadership Styles on Organizational Performance at State Corporations in Kenya. International Journal of Business and Commerce.

91. Quinn, A., Lemay, G., Larsen, P., \& Johnson, D. M. (2009). Service quality in higher education. Total Quality Management and Business Excellence. https://doi.org/10.1080/ 